\title{
Palatability Trials on Merker grass (Pennisetum purpureum), Venezuela grass (Paspalum fasciculatum), and Plantain Pseudo- stalks (Musa paradisiaca)
}

\author{
L. Rivera-Brenes, J. Herencia, J. A. Arroyo, and J. I. Cabrera ${ }^{1}$
}

\section{INTRODUCTION}

Merker grass is the most important soilage grass actually grown in Puerto Rico. Besides its high yield per acre, from 70 to 100 tons, its high palatability is well known to all farmers.

Venezuela grass was introduced from Venezuela, South America, to this Station several years ago; that accounts for its name (2) ${ }^{2}$. In Venezuela this grass is known as of Chiguirera grass $(5,6)$ and is a pest in the low wet lands due to its aggressiveness and poor palatability. Cattle eat some of it when it is young and tender, but as soon as it matures they reject it (5). A similar situation was observed at Rio Piedras (6) and, because of this, it was decided to perform palatability trials before making any recommendation.

Plantain pseudostalks are known to be eaten by cattle, but they are not usually used as forage. Around 29,000 acres were planted to plantains and bananas in 1956-57 (1). It is a common practice in Puerto Rico to cut and throw away the stalks after the fruit bunches are harvested. These stalks weigh around 40 pounds each on the average, and there are 600 plants to the acre. Production per acre is estimated thus as being about 12 tons; a total of 348,000 tons production is estimated for the whole Island.

Prolonged dry periods are not uncommon in Puerto Rico. During the year 1955-56 the Island suffered nearly 8 months of drought, and many head of cattle died from hunger. The economic losses due to reductions in weight were incalculable. Every year the northern section of Puerto Rico suffers a 30- to 60-day dry period and the south and southwest is dry from 60 to 120 days.

Unfortunately, most of the cattle owners do not practice any forage preservation by making hay or silage during the time of luxurious growth of the grass in the summer and, when the dry period arrives, they give cattle whatever they can find: cane tops, tree leaves, etc.

1 Animal Husbandman, Head of Department; Assistant Animal Husbandman; Assistant Chemist; and Assistant Animal Husbandman; Agricultural Experiment Station, University of Puerto Rico, Río Piedras, P. R.

2 Italic numbers in parentheses refer to Literature Cited, p. 254. 
Observations on the palatability of Venezuela and Pangola grasses were reported by Rivera-Brenes (6). Further palatability trials on these grasses and on plantain pseudostalks were made and are reported in this paper.

\section{PROCEDURE}

The experiment consisted of three trials using a $3 \times 3$ latin-square design with a 7-day prefeeding period and a 7-day collection period (2). Four animals were used per group.

The first experiment was run during July and August 1957; Merker and Venezuela grasses were compared. In the second experiment during July and August 1958, Merker grass, Venezuela grass, and plantain pseudostalks were compared, and in the third experiment during November and December 1958, Merker and Venezuela grasses were compared again.

The grasses were cut at ages between 40 and 60 days, when very green and tender. They were both fertilized with 400 pounds of ammonium sulfate. The plantain pseudostalks were gathered from one of the Substation farms after the bunches were harvested. They were over a year old.

During the second trial the Merker grass plots did not produce enough roughage to finish the experiment and grass of more or less the same age and condition from a nearby field was utilized to finish it. No difference was observed.

The grasses were chopped in a silage chopper each morning. The plantain pseudostalks were chopped in small pieces by hand with a machete. Samples were taken for the determination of moisture content and calculation of dry-matter intake. Digestability determinations were also made. They will be reported separately.

Dry cows and 2-year-old heifers were used, open or less than 5 months pregnant. They were weighed every morning during the collection periods. Total consumption was measured every day. Forages were offered to the animals in three or four servings during the day. At night they were put out in an exercise lot where they had access only to water. Both fresh-material and dry-matter consumption were calculated per 100 pounds of live weight for uniformity.

The percentage of leaves and stem was determined for Venezuela grass. A total of 11 samples was taken during the three trials. Each sample consisted of from 8 to 15 culms as they were cut in the field to be fed. Leaves, with leaf-sheaths attached were separated from the stems and both parts were weighed separately. Chemical analyses were made according to official methods.

\section{RESULTS AND DISCUSSION}

Average consumption of fresh forage and dry-matter per 100 pounds of live weight is presented in table 1 . The average chemical analyses for crude protein and dry matter are given in table 2. 
Merker grass, besides being much higher in protein content than Venezuela grass, is also higher in dry-matter content. Plantain pseudostalks were very low in both protein and dry-matter content.

Venezuela grass had a leaf-to-stem ratio of 48.57 to 51.43 percent, respectively. In this respect it is similar to Merker grass (7).

Although no study was made as to how each of these forages maintained the weight of the animals, it was observed from the daily weights that the cows on Merker grass did not lose weight, those on Venezuela grass lost weight, and those on plantain pseudostalks lost some weight, but not as much as those on Venezuela grass. However, those on Venezuela grass and

TABLE 1.-Pounds of fresh forage and dry maller consumed per 100 pounds of live weight for the 3 trials, all animals included

\begin{tabular}{c|c|c|c|c|c}
\hline \multicolumn{2}{c|}{ Merker grass } & \multicolumn{2}{c|}{ Venezuela grass } & \multicolumn{2}{c}{ Plantain pseudostalks } \\
\cline { 2 - 6 } Fresh forage & Dry matter & Frcsh forage & Dry matter & Fresh forage & Dry matter \\
\hline 10.02 & 2.00 & 3.93 & 0.69 & 14.93 & 0.80 \\
\hline
\end{tabular}

11 trial.

TABLe 2.-Crude-protein and dry-malter contents (percent) of the grasses and plantain pseudostalks, average of all trials

\begin{tabular}{l|c|c}
\hline \multicolumn{1}{c|}{ Forage } & Crude protein & Dry matter \\
\cline { 2 - 3 } Venezuela grass & 7.07 & 19.16 \\
Merker grass & 11.17 & 21.16 \\
Plantain pseudostalks & 4.52 & 5.87 \\
\hline
\end{tabular}

plantain pseudostalks gained in weight after they were changed to Merker grass.

The statistical analysis of the consumption data is presented in table 3 . Merker grass was more platable than Venezuela grass. The difference was highly significant.

It is to be noted in the second trial that the cows consumed more plantain pseudostalks than Merker grass; the difference was significant as to green matter consumed, but when dry matter was computed, it was less so. There is no doubt though that plantain pseudostalks are very palatable and that they can properly be used to feed cows in cases of emergency.

Venezuela grass is poor in palatability. This has been observed in its country of origin. When this grass is young, the animals eat some, but not too much, as demonstrated by this experiment.

It was also observed that when this Venezuela grass was chopped all the cut edges became reddish in color, as if they were oxidized. The chopped 
material also smelled like linseed oil which is probably the cause of its repellent bad taste. A chemical analysis revealed that this grass contains 0.02 percent of an unknown essential oil or oils.

Expressing the differences found on a percentage basis and taking Merker grass consumption as 100 percent, the consumption of Venezuela grass was 39 percent and that of plantain pseudostalks 149 percent, on a wet basis.

TABLE 3.-Statistical analysis of the results on palalability as pounds of green roughage and dry matter consumed per $100 \mathrm{lb}$. of liveweight

\begin{tabular}{|c|c|c|c|c|c|c|}
\hline Forage & $\begin{array}{c}\text { Green } \\
\text { foragel }\end{array}$ & $\underset{\text { matter' }}{\text { Dry }}$ & \multicolumn{2}{|c|}{ Green forage L.S.D. } & \multicolumn{2}{|c|}{ L.S.D. for dry matter } \\
\hline $\begin{array}{l}\text { Merker grass } \\
\text { Venezuela grass }\end{array}$ & $\begin{array}{r}11.79 \\
5.29\end{array}$ & $\begin{array}{l}2.35 \\
1.03\end{array}$ & $(0.01)$ & $(0.05)$ & $(0.01)$ & $(0.05)$ \\
\hline Difference & $6.50 * *$ & $1.32^{* *}$ & 1.45 & 1.04 & .35 & .25 \\
\hline $\begin{array}{l}\text { Plantain pseudostalks } \\
\text { Merker grass }\end{array}$ & $\begin{array}{r}14.93 \\
9.53\end{array}$ & $\begin{array}{l}0.80 \\
1.86\end{array}$ & & & & \\
\hline Difference & $5.40^{*}$ & $1.06^{* *}$ & 5.49 & 2.39 & .99 & .43 \\
\hline $\begin{array}{l}\text { Plantain pseudostalks } \\
\text { Venezuela grass }\end{array}$ & $\begin{array}{r}14.93 \\
2.90\end{array}$ & $\begin{array}{r}0.80 \\
.36\end{array}$ & & & & \\
\hline Difference & $12.03^{* *}$ & $0.44^{*}$ & & & & \\
\hline $\begin{array}{l}\text { Merker grass } \\
\text { Venezuela grass }\end{array}$ & $\begin{array}{l}9.53 \\
2.90\end{array}$ & $\begin{array}{r}1.86 \\
.36\end{array}$ & & & & \\
\hline Difference & $6.63^{* *}$ & $1.50^{* *}$ & 5.49 & 2.39 & 1.34 & .59 \\
\hline $\begin{array}{l}\text { Merker grass } \\
\text { Venezuela grass }\end{array}$ & $\begin{array}{l}9.20 \\
3.61\end{array}$ & $\begin{array}{r}1.95 \\
.70\end{array}$ & & & & \\
\hline Difference & $5.59^{* *}$ & $1.25^{* *}$ & 1.46 & 1.05 & .19 & .14 \\
\hline
\end{tabular}

$1 * *$ indicates significance at 1 -percent level; * at 5 percent.

Figure 1 presents graphicaly the dry-matter consumption by a $900-$ pound cow of Merker grass, Venezuela grass, and plantain pseudostalks.

According to Morrison standards (3) a 900-pound cow needs from 6.4 to 7.2 pounds of T.D.N. for maintenance. Assuming 50-percent T.D.N. for the dry matter consumed in the forages under test, Merker grass produced almost 2 pounds of T.D.N. over Morrison's high limit. Venezuela grass was short by 2.8 pounds from the low limit, and plantain pseudostalks were short by 3.3 pounds from the low limit. 


\section{SUMMARY AND CONCLUSIONS}

Venezuela grass (Paspalum fassiculatum) was introduced to Puerto Rico some years ago from Venezuela, South America. Poor palatability was observed as well as its aggressiveness on the low wet lands in the Experiment Station Farm.

Several thousand acres are planted to bananas and plantains (Musa paradisiaca) in the Island. The pseudostalks are known to be eaten by cattle, but almost all of them are thrown away after the banana bunches are harvested.

Merker grass (Pennisetum purpureum) is the standard soilage grass used and it is very palatable.

Three palatability trials were run to test Venezuela grass, plantain pseudostalks, and Merker grass as a check.

Dry matter (pounds)

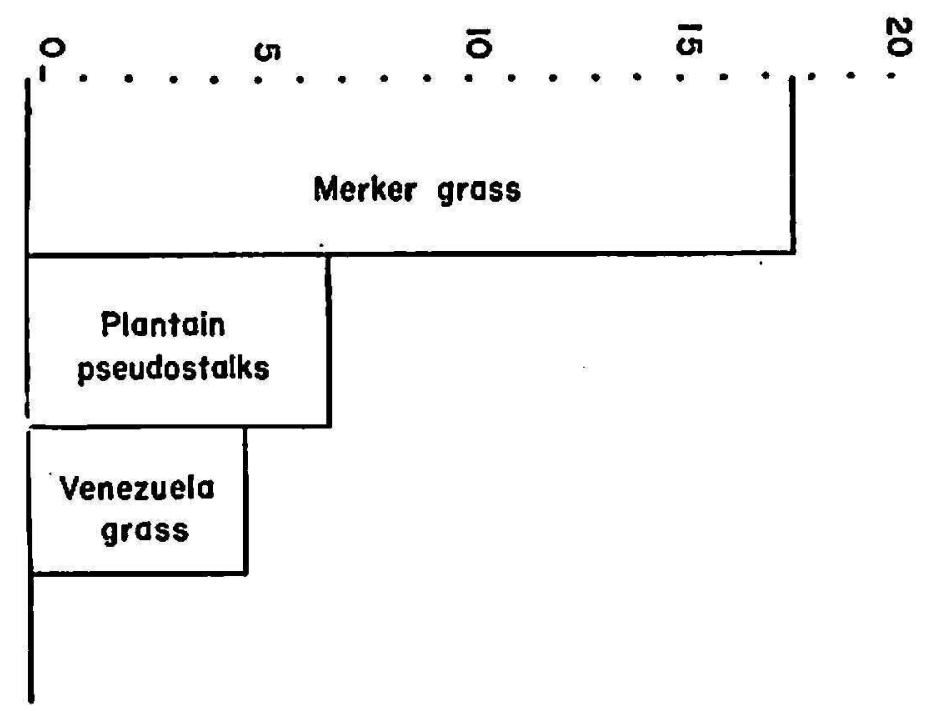

FrG. 1.-Dry-matter consumption by a 900-pound cow of Merker grass, Venezuela grass, and plantain pseudostalks.

Taking the consumption of Merker grass as 100 percent, wet basis, the consumption of Venezuela grass was 39 and that of plantain pseudostalks 149 percent. The differences were statistically significant on both the wet and dry bases.

Plantain pseudostalks contain very little dry matter and should be used only in emergencies.

In the Island we have pasture grasses with recognized good palatability like Pangola, Guinea, Para, Molasses, and others. In any pasture-improvement program on the farm any one of these is preferable to Venezuela grass.

\section{RESUMEN}

La yerba Venezolana, (Paspalum fassiculatum) se introdujo a Puerto Rico de Venezuela, Sur América. Se había observado que esta yerba no era 
muy apetecida por el ganado y se sabía también de su crecimiento muy agresivo en los terrenos llanos y pantanosos de la finca de la Estación Experimental Agrícola de la Universidad de Puerto Rico, en Río Piedras.

En Puerto Rico se siembran miles de cuerdas de plátanos y guineos. Se sabe que el ganado se come algunos tallos, pero casi todos estos se botan luego de cosechados los racimos.

La yerba Merker es la yerba principal para corte en la Isla. El ganado la apetece mucho.

Se llevaron a cabo tres experimentos para determinar la aceptación que tenía el ganado por la yerba Venezolana antes de hacer otras evaluaciones y para ver la utilidad que se le podría dar a los tallos de las plantas de plátano como forraje. Se usó la yerba Merker como testigo para las comparaciones.

Cuando se tomó el consumo de la yerba Merker a un porcentaje de 100, el consumo de la yerba Venezolana llegó a un 39 por ciento y el de los tallos de plátano a un 149 por ciento. Las diferencias en consumo, tanto para el material fresco como a base de materia seca, fueron altamente significativas.

Los seudo-tallos de plátano contienen muy poca materia seca y se recomienda su uso solamente en casos de emergencia.

En la Isla hay un número de yerbas apetecidas por el ganado, tales como la Pangola, la Guinea, el Malojillo, la Melao y otras. En cualquier programa de mejoramiento de pastos en la finca debe preferirse una de éstas a la Venezolana.

\section{LITERATURE CITED}

1. Anonymous, Summary of a conference held at Beltsville, February 20-21, 1956, on procedures and technics used in silage studies, U. S. Department of Agriculture, Washington, D. C., L. A. Moore, Chairman.

2. Annual Book of Statistics, Commonwealth Department of Agriculture, San Juan: P. R., 1956-57.

3. Morrison, F. B., Feeds and Feeding ed. 22, 1956, The Morrison Publishing Co., Ithaca, N. Y.

4. Personal communications to the author by Prudencio Nogales, Agronomist of the Ministry of Agriculture of Venezuela and Antonio Duque Herrera, farmer in the Valencia region, Province of Carabobo of the same country, 1956.

5. Ramia, M., Pastos de los llanos de Barinos, Bol. de la Soc. Venezolana de Ciencias Nat. 17 (87) p. 300, Julio 1957.

6. Rivera-Brenes, L., Progress Report to the Director of the Agricultural Experiment Station of the University of Puerto Rico, 1955; unpublished.

7. - Technical and Economic Aspects of Roughage Production in Puerto Rico, Agr. Exp. Sta., Univ. P. R. Tech. Paper 12, Sept. 1953., Rio Piedras, P. R. 